\title{
ONTOGENIC DELAYS IN EFFECTS OF NITRITE EXPOSURE ON TIGER SALAMANDERS (AMBYSTOMA TIGRINUM TIGRINUM) AND WOOD FROGS (RANA SYLVATICA)
}

\author{
KERRY L. GRIFFIS-KYLE* \\ 130 College Place, Department of Biology, Syracuse University, Syracuse, New York 13244, USA
}

(Received 10 September 2004; Accepted 14 December 2004)

\begin{abstract}
Under certain conditions, nitrite can be present in freshwater systems in quantities that are toxic to the fauna. I exposed wood frog (Rana sylvatica) and eastern tiger salamander (Ambystoma tigrinum tigrinum) embryos and young tadpoles and larvae to elevated concentrations of nitrite in chronic toxicity tests: $0,0.3,0.6,1.2,2.1,4.6$, and $6.1 \mathrm{mg} / \mathrm{L} \mathrm{NO}_{2}-\mathrm{N}$, exposing individuals as both embryos and larvae. Nitrite caused significant declines in wood frog hatching success $\left(3.4 \mathrm{mg} / \mathrm{L} \mathrm{NO} \mathrm{N}_{2}-\mathrm{N}\right.$, wood frog), and lower concentrations caused significant mortality during the early larval stages $\left(4.6 \mathrm{mg} / \mathrm{L} \mathrm{NO} \mathrm{NO}_{2}-\mathrm{N}\right.$, salamander; $0.5 \mathrm{mg} / \mathrm{L} \mathrm{NO}$ - $\mathrm{N}$, wood frog). Later tests exposing individuals to nitrite only after hatching showed that both wood frog and tiger salamander vulnerability to nitrite declined shortly after hatching. Hence, examining a single life-history stage, especially later in development, may miss critical toxic effects on organisms, causing the researcher potentially to underestimate seriously the ecological consequences of nitrite exposure.
\end{abstract}

Keywords-Amphibian declines Nitrite Wood frog Eastern tiger salamander Ontogenic delays

\section{INTRODUCTION}

Many amphibian populations have declined over the past several decades, often in response to anthropogenic stressors. Researchers have linked these declines to various causes, including habitat fragmentation and destruction, exotic species invasions, harvesting, pollution, and natural fluctuations [110]. Over the last century, increased fossil fuel consumption, fixation of previously unavailable gaseous $\mathrm{N}_{2}$ for fertilizer, as well as other anthropogenic activities, have doubled the amount of available $\mathrm{N}$ in the environment [11]. This mineral $\mathrm{N}$ can have direct toxic effects on aquatic organisms.

Mineral $\mathrm{N}$ in freshwater systems can decrease survival in aquatic vertebrates by disrupting amino acid metabolism [12], enzyme activity [13], and the blood's ability to transport oxygen [14-16]. Consequently, large increases in amphibian mortality may occur as a result of higher anthropogenically driven $\mathrm{N}$ concentrations expected over the next 50 years [11,17-19].

Mineral $\mathrm{N}$ is an underappreciated threat to amphibians and other organisms, probably because of the timing of high nitrogen concentrations in the environment. Concentrations of mineral $\mathrm{N}$ can be very high in ponds and wetlands in winter and early spring ([20,21], K. L. Griffis-Kyle, unpublished data) because plant and microbial uptake has not yet begun or is very minimal. This is when many amphibians reproduce [2224]; hence, these embryos and young tadpoles are exposed to elevated concentrations of $\mathrm{N}$ during very vulnerable life stages $[25,26]$. However, no studies link the timing of mineral $\mathrm{N}$ peaks in the environment with vulnerable periods in amphibian development and examine delayed effects in later life-history stages. Moreover, researchers have just begun to examine how sublethal effects of any toxicant at an early developmental stage can increase significantly mortality at later stages

\footnotetext{
* To whom correspondence may be addressed (klgriffi@syr.edu).
}

$[27,28]$. If this pattern holds for mineral $\mathrm{N}$, we seriously may be underestimating the impact $\mathrm{N}$ could be having on amphibian populations.

I examined nitrite's lethal and sublethal effects on egg hatching and tadpole and larval survival of early breeding amphibians, the eastern tiger salamander (Ambystoma tigrinum tigrinum) and the wood frog (Rana sylvatica). I also examined consequences of embryonic exposure to nitrite by exploring carryover effects of mineral $\mathrm{N}$ in tiger salamander larvae and wood frog tadpoles, and I continued to follow the effects on wood frog tadpoles through metamorphosis.

\section{METHODS}

Study organisms

Wood frogs (R. sylvatica) are common in the northern United States and Canada. They breed in shallow ponds of varying hydroperiods. Eastern tiger salamanders (A. tigrinum tigrinum) are common in eastern North America and into Canada. In Minnesota, adults of both species arrive at ponds as the ice melts and lay their eggs over several weeks. I collected a total of five wood frog egg masses from four ponds in 2002 and 2004; one pond was visited during both years, and a total of 28 eastern tiger salamander egg masses was collected from six ponds in 2003 and 2004. Egg masses (wood frog: Gosner [29] stage 10; tiger salamander: Shi and Boucaut [30] stage 16) were returned to the laboratory and broken up into smaller clusters for hatching experiments.

\section{Test conditions}

I used well water from Cedar Creek Natural History Area (Bethel, MN, USA) filtered to remove rust, sediments, chlorine, lead, and bacteria using an Omnifilter system (filters RS55 and CB3, Delavan, WI, USA). The filtered water had a $\mathrm{pH}$ $8.2,304.5 \mu \mathrm{S} / \mathrm{cm}$ conductivity, $121 \mathrm{mg} / \mathrm{L}$ total alkalinity, $<2$ $\mathrm{mg} / \mathrm{L}$ total hardness, $0.05 \mathrm{mg} / \mathrm{L} \mathrm{NO}_{3}-\mathrm{N}, 0 \mathrm{mg} / \mathrm{L} \mathrm{NO}_{2}-\mathrm{N}$, and 
$0 \mathrm{mg} / \mathrm{L} \mathrm{NH}_{3}$-N. I used 3-L clear Sterilite containers and 0.4L opaque Solo cups, randomly placed on five-shelf shelving units (183-cm tall, 46-cm deep, 91-cm wide). Containers held five cups of the same concentration to minimize possible contamination between treatments. Lighting approximated the natural photoperiod and provided the full spectrum of light radiation. The containers were cleaned for all experiments twice weekly, keeping the same nitrite treatment concentration (sodium nitrite $99.60 \%$ pure, A.C.S. Fisher Scientific, Fair Lawn, NJ, USA).

At three times during the experiment in 2004, I sampled the testing water for mineral $\mathrm{N}$ just before the cages were cleaned. I did not sample water during the 2003 tests. I collected $50 \mathrm{ml}$ of fluid from 5 pseudo-randomly chosen containers per species (Microsoft Excel pseudo-random number generator). I filtered these samples through combusted glass fiber filter (GF/F) Whatman (Clifton, NJ, USA) 25-mm filters and immediately (less than $2 \mathrm{~min}$ ) froze the samples [31]. These samples were analyzed for ammonium, nitrate, and nitrite colorimetrically with an Alpkem autoanalyzer (College Station, TX, USA) at Cedar Creek Natural History Area (modified from [32]). I also measured dissolved oxygen (YSI probe, Yellow Springs, OH, USA), pH, and temperature (Hannah probe, Woonsocket, RI, USA) in all containers weekly in 2004.

Actual treatment concentrations are reported below as ranges, but these ranges were not significantly different between species $(F=1.4$, degrees of freedom $[d f]=1, p=0.3)$; therefore, I am reporting treatment ranges for both species combined. For embryos, nitrite increased between cleanings, and actual treatment concentrations were as follows: 0 to 0.0 , 0.3 to $0.5,0.6$ to $0.7,1.2$ to $1.5,2.1$ to $2.3,4.6$ to 4.9 , and 6.1 to $7.7 \mathrm{mg} / \mathrm{L} \mathrm{NO}-\mathrm{N}$. For tadpoles and larvae, the actual treatments concentrations were 0 to $0.27,0.3$ to $0.59,0.6$ to $0.9,1.2$ to $1.4,2.1$ to $2.2,4.6$ to 5.0 , and 6.1 to $7.6 \mathrm{mg} / \mathrm{L} \mathrm{NO}_{2}-$ $\mathrm{N}$. Ammonium averaged $0.3 \mathrm{mg} / \mathrm{L} \mathrm{N}$ (standard error $[\mathrm{SE}]=$ $0.01)$ in the embryo treatments and $0.5 \mathrm{mg} / \mathrm{L} \mathrm{N}(\mathrm{SE}=0.01)$ in the tadpole and larvae treatments. The $\mathrm{pH}$ averaged 8.2 (SE $=0.003)$, and temperature averaged $17.8^{\circ} \mathrm{C}(\mathrm{SE}=0.03)$.

\section{Embryos}

I split egg masses randomly into groups of 10 eggs so that each group had eggs from at least two different egg masses. Eggs that were discolored were excluded from the test. I placed one group into each 3-L container, with five replicate containers per treatment per species, and applied seven treatment levels $\left(0,0.3,0.6,1.2,2.1,4.6\right.$, and $6.1 \mathrm{mg} / \mathrm{L} \mathrm{NO}_{2}-\mathrm{N}$ derived from sodium nitrite) for tiger salamanders in 2004 and wood frogs in 2002 and 2004. In 2003, I applied four treatment levels $\left(0,1.5,3.0\right.$, and $4.6 \mathrm{mg} / \mathrm{L} \mathrm{NO}_{2}-\mathrm{N}$ derived from sodium nitrite) to tiger salamanders. Treatment concentrations were based on data from a pilot project on wood frogs in 2002. Containers randomly were assigned locations and placed on two shelving units.

\section{Larvae}

I used 20 (2002) and 30 (2004) randomly chosen wood frogs and 30 (2004) randomly chosen tiger salamanders that hatched during the embryo experiments per treatment level of nitrite for a total of 350 wood frogs and 210 tiger salamanders. Individuals were removed from the hatching containers within $24 \mathrm{~h}$ of hatching. If fewer than 20 (2002) or 30 (2004) individuals hatched for a given species in a given treatment, I used as many as available. I tested early tadpole and larval survival at nitrite concentrations of $0,0.3,0.6,1.2,2.1,4.6$, and 6.1 $\mathrm{mg} / \mathrm{L} \mathrm{NO}_{2}-\mathrm{N}$ derived from sodium nitrite. Tiger salamanders were examined for $26 \mathrm{~d}$ of exposure because of logistical constraints in feeding. All tadpoles and larvae were housed individually in $0.4 \mathrm{~L}$ of water. I fed larvae (brine shrimp) and tadpoles (algae) daily and supplied tadpoles with boiled lettuce and fish food on an ad libidum basis. I changed water twice each week. Mortality was tallied daily.

Amphibian susceptibility to nitrite may vary based on when during development the individual is exposed to nitrite. To assess the window of time when the amphibians are vulnerable to nitrite exposure, I began chronic toxicology experiments at several stages of development after hatching: Wood frogs at Gosner [29] stages 25 (feeding), 27, and 29 in 2004 and tiger salamanders at Shi and Boucaut [30] stages 34 and 36 in 2003. I used individuals that were hatched at $0 \mathrm{mg} / \mathrm{L} \mathrm{NO}_{2}-\mathrm{N}$. I used 10 individuals per treatment per developmental stage at three treatment concentrations for wood frogs $(0,0.6$, and $1.2 \mathrm{mg} /$ $\mathrm{L} \mathrm{NO}_{2}-\mathrm{N}$ ) and seven treatment concentrations for tiger salamanders $\left(0,0.3,0.6,1.2,2.1,3.0\right.$, and $\left.4.6 \mathrm{mg} / \mathrm{L} \mathrm{NO}_{2}-\mathrm{N}\right)$. Individuals were fed and water was changed as described for earlier chronic toxicology experiments. Mortality was tallied daily.

\section{Analysis}

We multiplied the proportion survived to hatching by the proportion of tadpoles survived per container (five 0.04-L cups per container) to calculate overall survival per treatment. I pooled 2002 and 2004 wood frog data to analyze effects of nitrite after $34 \mathrm{~d}$ of exposure, after which the 2002 experiment was taken down. Wood frog survival to metamorphosis is from 2004 data only. I used linear regression to evaluate effects of increasing nitrite exposure [33]. I used general linear models [33] to evaluate differences between treatments and between species for evaluating treatment ranges, and for evaluating differences between individuals exposed to nitrite as embryos, and individuals not exposed until after hatching.

\section{RESULTS}

\section{Embryos}

The mean percentage of eggs that hatched per treatment concentration varied between 0 and $100 \%$ for wood frogs, and between 86 and $98 \%$ for tiger salamanders. The proportion of wood frog eggs that hatched declined significantly with increasing nitrite concentration $\left(r^{2}=0.22, p<0.0005\right)$ (Fig. $1 \mathrm{~A})$; however the proportion of tiger salamander eggs that hatched was not related to nitrite exposure at the concentrations we tested ( $\left.r^{2}=0.04, p=0.15\right)$ (Fig. 1B).

\section{Tadpoles}

Mean wood frog 34-d survival, beginning as an embryo and continuing into the tadpole stage, ranged from 0 to $58 \%$. Mean tiger salamander 26-d survival, beginning as an embryo and continuing into the larval stage, ranged from 0 to $98 \%$. Nitrite had a significant negative effect on larval wood frog and tiger salamander survival $\left(r^{2}=0.54, p<0.0005 ; r^{2}=\right.$ $0.63, p<0.0005$ respectively; Fig. 2).

The proportion of wood frogs that metamorphosed (Gosner [29] stage 46) ranged from 0 to $42 \%$. Nitrite had a significant negative effect on the proportion of wood frogs surviving through metamorphosis $\left(r^{2}=0.34, p<0.0005\right.$; Fig. 3).

Of the treatments exposed to nitrite only after hatching (beginning exposure at Gosner [29] stage 25, 27, and 29, and 
(A)

Wood frog

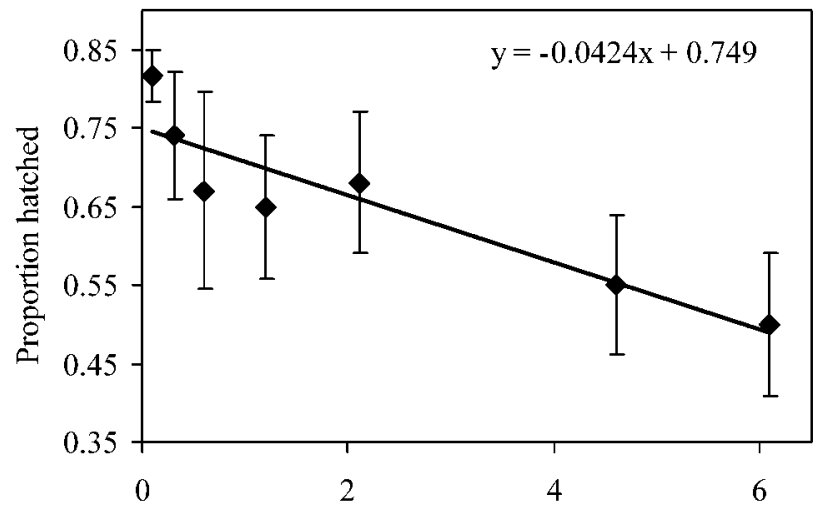

Concentration (mg/L NO2-N)

(B)

Eastern tiger salamander

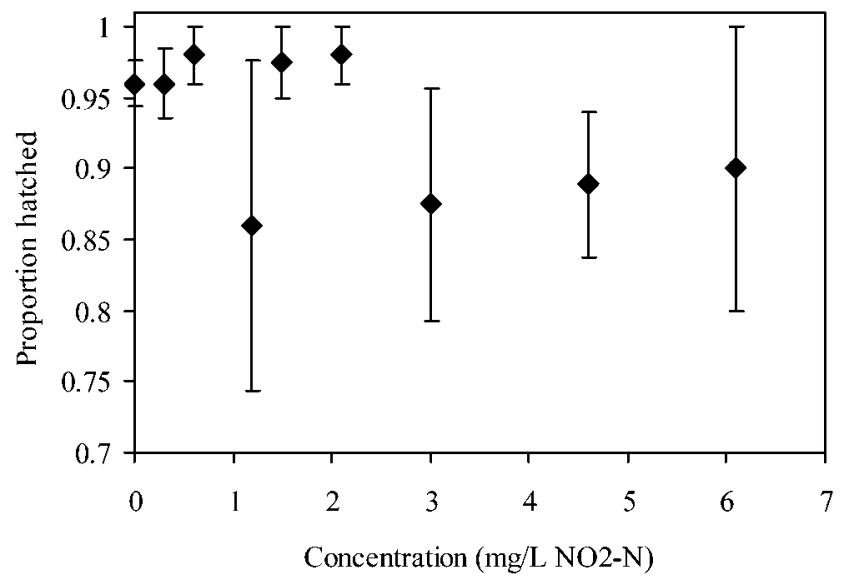

Fig. 1. Regression of the proportion of (A) wood frog and (B) eastern tiger salamander eggs that hatched (average and standard error) in relation to exposure concentration of nitrite.

Shi and Boucaut [30] 34 and 36), wood frogs experienced no mortality (34 d) and only one tiger salamander died (26 d). Forty percent of the wood frogs not exposed as embryos that were exposed to 0.6 and $1.2 \mathrm{mg} / \mathrm{L} \mathrm{NO}_{2}-\mathrm{N}$ survived through metamorphosis, whereas, only 13 and $23 \%$ of the individuals survived in those concentrations that were exposed since they were embryos. The $40 \%$ survival in the treatments that did not receive exposure as embryos was no different from the $41 \%$ survival in the control treatment $(F=0.2, p=0.7)$. The $98 \%$ survival over all treatments in tiger salamanders not exposed as embryos was no different from the $100 \%$ survival in the control treatment $(F=0.4, p=0.5)$.

\section{DISCUSSION}

Exposure to nitrite at concentrations greater than $3.4 \mathrm{mg} /$ $\mathrm{L} \mathrm{NO}_{2}-\mathrm{N}$ cuts wood frog hatching in half. Laposata and Dunson [34] also examined wood frog hatching, but explored nitrate exposure, which generally is less toxic than nitrite, and did not find an effect on hatching at the concentrations they tested, 0 to $40 \mathrm{mg} / \mathrm{L} \mathrm{NO}_{3}\left(0\right.$ to $\left.0.9 \mathrm{mg} / \mathrm{L} \mathrm{NO}_{3}-\mathrm{N}\right)$. Schuytema and Nebeker [25] exposed amphibian eggs both to ammonium nitrate and sodium nitrate and measured mortality at $6.7 \%$ at $13.3 \mathrm{mg} / \mathrm{L} \mathrm{NH}_{4}-\mathrm{N}$ and $20 \%$ at $230 \mathrm{mg} / \mathrm{L} \mathrm{NO}_{3}-\mathrm{N}$ for Pseu-
(A)

Wood Frog

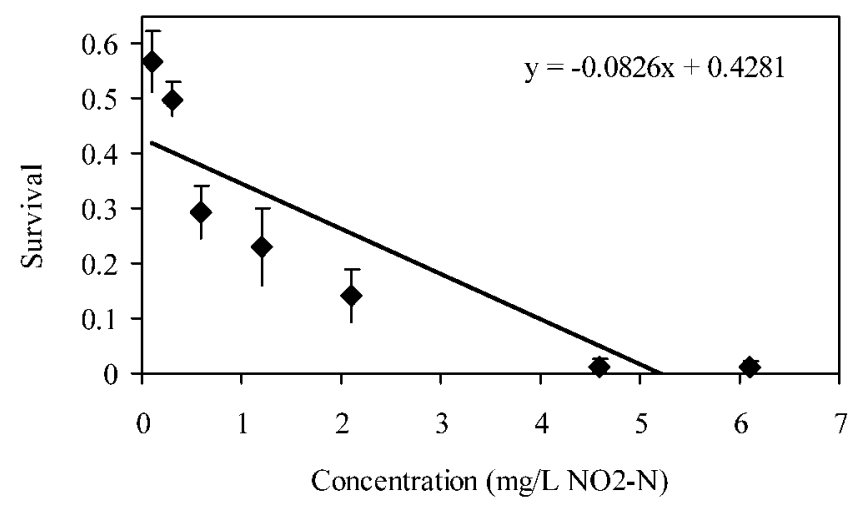

(B) Eastern tiger salamander

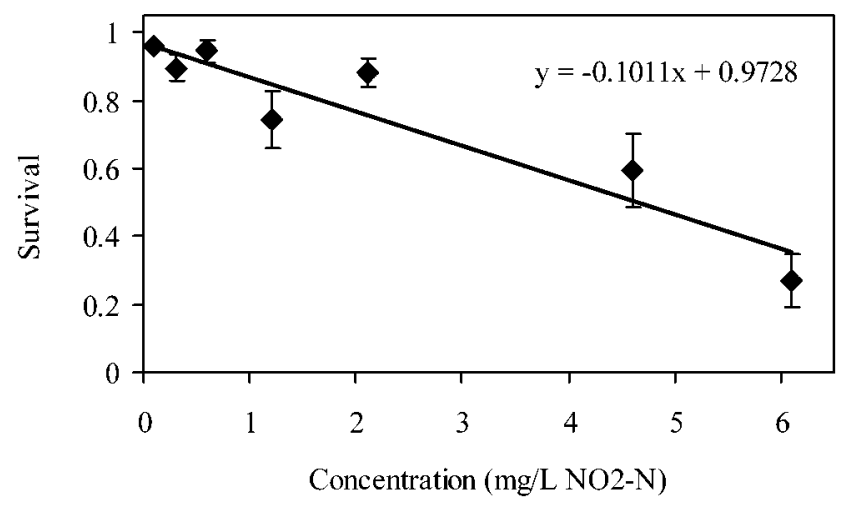

Fig. 2. Regression showing the negative relationship between the proportion of (A) wood frog surviving to $34 \mathrm{~d}$ and (B) eastern tiger salamanders surviving to $26 \mathrm{~d}$ in relation to exposure concentration of nitrite.

doacris regilla over $10 \mathrm{~d}$, and $3.3 \%$ at $6.9 \mathrm{mg} / \mathrm{L} \mathrm{NH}_{4}-\mathrm{N}$ and $3.3 \%$ at $24.8 \mathrm{mg} / \mathrm{L} \mathrm{NO}_{3}-\mathrm{N}$ for Xenopus laevis over $5 \mathrm{~d}$. These tests were stopped before the embryos hatched, perhaps causing the effects of mineral $\mathrm{N}$ on embryos to be underestimated (see discussion below). Mineral $\mathrm{N}$ decreased hatching in most

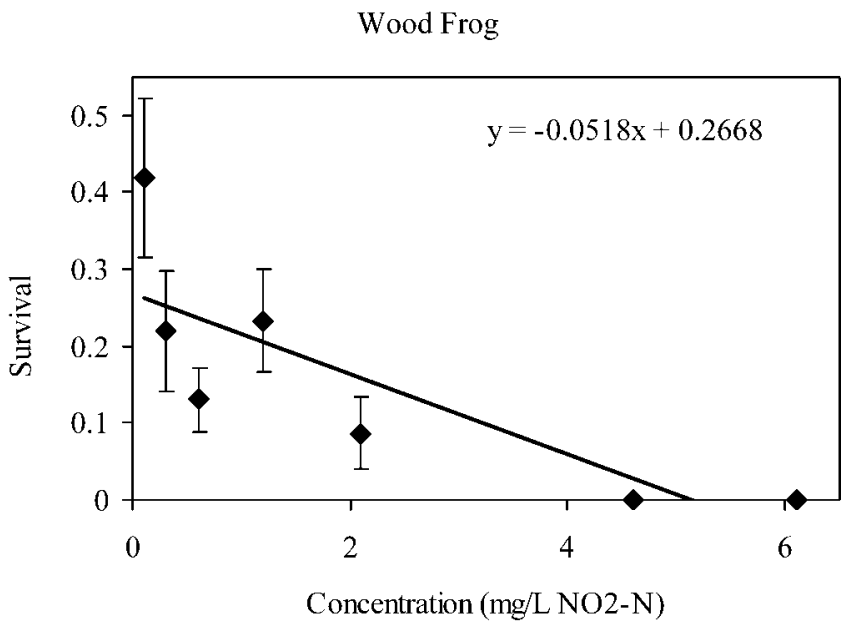

Fig. 3. Regression showing the negative relationship between the proportion of wood frogs surviving to metamorphosis in relation to exposure concentrations of nitrite. Metamorphosis occurred between 80 and $106 \mathrm{~d}$ of first exposure to nitrite. 
species tested. Hence, species such as the wood frog that breed early in the year may be more vulnerable ecologically to mineral $\mathrm{N}$ toxicity because of the coincidence between embryonic stages and high mineral $\mathrm{N}$ concentrations in the water.

I found that nitrite causes significant mortality in wood frog tadpoles and tiger salamander larvae. Marco et al. [35] also found significant mortality from nitrite in two of the four species they tested, Ambystoma gracile and Rana pretiosa, after $15 \mathrm{~d}$. At concentrations comparable to my experiments, they had an increase in mortality from 0 to $15 \%$ for tadpoles exposed to nitrite within a week after hatching. Additional researchers have examined the effects of other forms of mineral $\mathrm{N}$ on amphibian larvae. Hecnar [36] found significantly lower Pseudacris triseriata and Rana pipiens tadpole survivorship exposed to $10 \mathrm{mg} / \mathrm{L} \mathrm{NO}_{3}$-N over $100 \mathrm{~d}$ when tadpoles initially were exposed at stage 25. Watt and Jarvis [37] found significant mortality for palmate newt larvae exposed to $50 \mathrm{mg} / \mathrm{L}$ ammonium nitrate, when larvae were exposed after they were six weeks old. Xu and Oldham [38] found common toad tadpoles (Bufo bufo), Gosner [29] stages 32 through 35 were susceptible to ammonium nitrate over $7 \mathrm{~d}$ only at very high concentrations $1,935 \mathrm{mg} / \mathrm{L}$ ammonium nitrite $(387 \mathrm{mg} / \mathrm{L} \mathrm{N})$. All of these other studies began exposure after the embryonic period. Our studies, as well as others, demonstrate that mineral nitrogen, whether in the form of nitrite ammonium or nitrate, are toxic to larval amphibians.

My data suggest that both wood frogs and tiger salamanders have a much lower resistance to nitrite toxicity when individuals are exposed initially as embryos, and that most of the mortality caused by nitrite appears after hatching. At the concentrations I tested, individuals exposed to nitrite only after hatching showed no difference in mortality from individuals never exposed to nitrite, suggesting an ontogenic lag in mortality. Researchers have found other ontogenic time lags from toxicants. Greulich and Pflugmacher [27] found carryover effects of pesticide exposure and Rasanen et al. [28] found carryover effects of acidity exposure between embryonic and larval periods in amphibians. Nitrite affects organisms by oxidizing hemoglobin to methemoglobin, transforming the molecule's shape and effectively excluding it from binding with oxygen. Amphibian embryos take up oxygen through the egg surface, directly diffusing the oxygen through the embryo without the use of hemoglobin [39], so we should not expect to see a large effect of nitrite on mortality during embryonic stages. However, after the embryos hatch, nitrite enters the body into the circulatory system mainly through the chlorideuptake mechanisms in the gills [40]. Larval amphibians, which use hemoglobin for the transport of oxygen, then become susceptible to the effects of nitrite on oxygen transport. Hence, not only are larvae more susceptible to nitrite because of the way nitrite effects blood physiology, they also are more susceptible because nitrite is effecting embryonic development, making larval effects even more pronounced.

Nitrite, and very likely other forms of mineral $\mathrm{N}$, are more toxic than acknowledged previously because of the ontogenic lags in mortality between life stages. Others have examined toxic effects of mineral nitrogen on amphibians, but all have looked at a single life-history stage and, thus, may underrepresent actual sensitivity of amphibians to mineral nitrogen (e.g., [1,25,26,34-38]). Furthermore, researchers have reported widely divergent results even for the same species. Some of this variation is due to the type of mineral $\mathrm{N}$ used; nitrite and ammonium are more toxic than nitrate. However, much of this variation may be due to age at first exposure. For example, Pseudacris regilla is more susceptible as an embryo (37 mg/L $\left[\mathrm{NH}_{4}\right]_{2} \mathrm{SO}_{4}-\mathrm{N}$, lowest observable adverse effect level) [25] than at six weeks after hatching $\left(54 \mathrm{mg} / \mathrm{L}\left[\mathrm{NH}_{4}\right]_{2} \mathrm{SO}_{4}-\mathrm{N}\right.$, lowest observable adverse effect level) [26]. These results, in conjunction with my findings, suggest that traditional toxicology tests examining a single ontogenic stage, especially later in development, may miss critical toxic effects on organisms that may be reduced or eliminated with development, or effects that occur early in development but are not evident until later life stages. Traditional toxicology tests that only examine a single life-history stage may under-represent dramatically the potential consequences of toxin exposure to amphibians. These results imply that, based on past toxicological research, mineral $\mathrm{N}$ is an underappreciated threat to amphibian populations.

Increased amounts of mineralized nitrogen in the environment have become a mounting concern for both scientists and the public [11] and should be studied further for their role in amphibian declines. The coincidence of timing between early breeding amphibians and large environmental nitrogen concentrations allows the susceptible frog embryos to come in contact with high concentrations of mineral $\mathrm{N}$, potentially leading to increased mortality. Increased mortality could have large effects on population and community dynamics in freshwater systems. My research suggests that nitrite significantly can effect several amphibians' populations by increasing mortality. If we keep increasing nitrogen inputs into our environment, we may see declines in more and more aquatic species.

Acknowledgement-I would like to thank my funding sources, including the Declining Amphibian Populations Task Force, Syracuse University College of Arts and Sciences, and the National Science Foundation's Long-Term Ecological Research.

\section{REFERENCES}

1. Berger L. 1989. Disappearance of amphibian larvae in the agricultural landscape. Ecology International Journal 17:65-73.

2. Blaustein AR, Wake DB. 1990. Declining amphibian populations: A global phenomenon? Trends Ecol Evol 5:203-204.

3. Phillips K. 1990. Where have all the frogs and toads gone? BioScience 40:422-424.

4. Griffiths R, Beebee TJC. 1992. Decline and fall of the amphibians. New Sci 134:25-29.

5. Blaustein AR. 1994. Chicken Little or Nero's fiddle? A perspective on declining amphibian populations. Herpetologica 50:8597.

6. Blaustein AR, Hoffman PD, Hokit DG, Kiesecker JM, Walls SC, Hays JB. 1994. UV repair and resistance to solar UV-B in amphibian eggs: A link to population declines? Proc Natl Acad Sci USA 91:1791-1795.

7. Pounds JA, Crump ML. 1994. Amphibian declines and climate disturbance: The case of the golden toad and the harlequin frog. Conserv Biol 8:72-85.

8. Reaser JK. 1996. The elucidation of amphibian declines. Amphib Reptile Conserv 1:4-9.

9. Carey C, Cohen N, Rollins-Smith L. 1999. Amphibian declines: An immunological perspective. Dev Comp Immunol 23:459-472.

10. Kiesecker JM, Blaustein AR, Belden LK. 2001. Complex causes of amphibian population declines. Nature 410:681-683.

11. Vitousek PM, Aber JD, Howarth RW, Likens GE, Matson PA, Schindler DW, Schlesinger WH, Tilman DG. 1997. Human alteration of the global nitrogen cycle: Sources and consequences. Ecol Appl 7:737-750.

12. Arillo A, Margiocco C, Medlodia F, Mensi P, Henone G. 1981. Ammonia toxicity mechanism in fish: Studies on rainbow trout (Salmo gairdneri Rich.). Ecotoxicol Environ Saf 5:316-328.

13. Walsh PJ, Bergman HL, Narahara A, Wood CM, Wright PA, Randall DJ, Maina JN, Laurent P. 1993. Effects of ammonia on survival, swimming, and activities of enzymes of nitrogen me- 
tabolism in the Lake Magdi tilapia Oreochromis alcalicus grahami. J Exp Biol 180:323-387.

14. Sousa RJ, Meade TL. 1977. The influence of ammonia on the oxygen delivery system of coho salmon hemoglobin. Comp Biochem Physiol A 58:23-28.

15. Knoph MB, Thorud K. 1996. Toxicity of ammonia to Atlantic salmon (Soho salar L.) in seawater-Effects on plasma osmolality, ion, ammonia, urea, and glucose levels and hemotologic parameters. Comp Biochem Physiol A 113A:375-381.

16. Dappen GE. 1982. Effects of nitrates upon hemopoietic, lymphoid, and vascular tissues of tadpoles and frogs. Proceedings of the Nebraska Academy of Science Affiliated Society 92:23.

17. Galloway JN, Levy H, Kasibhatla PS. 1994. Year 2020: Consequences of population growth and development on deposition of oxidized nitrogen. Ambio 23:120-123.

18. Jeffries RL, Maron JL. 1997. The embarrassment of riches: Atmospheric deposition of nitrogen and community and ecosystem processes. Trends Ecol Evol 12:74-78.

19. Tilman D. 1999. Global environmental impacts of agricultural expansion: The need for sustainable and efficient practices. Proc Natl Acad Sci USA 96:5995-6000.

20. Rouse JD, Bishop CA, Struger J. 1999. Nitrogen pollution: An assessment of its threat to amphibian survival. Environ Health Perspect 107:799-803.

21. Oldham RS. 1999. Amphibians and agriculture: Double jeopardy. In Whitfield M, Matthews J, Reynolds C, eds, Aquatic Life-Cycle Strategies: Survival in a Variable Environment. Marine Biological Association of the United Kingdom, Plymouth, pp 105-124.

22. Wright AH, Wright AA. 1949. Handbook of Frogs and Toads of the United States and Canada, 3rd ed. Comstock, Ithaca, NY, USA.

23. Oldfield B, Moriarty JJ. 1994. Amphibians and Reptiles Native to Minnesota. University of Minnesota, Minneapolis, MN, USA.

24. Petranka JW. 1998. Salamanders of the United States and Canada. Smithsonian Institution, Washington, DC.

25. Schuytema GS, Nebeker AV. 1999. Comparative effects of ammonium and nitrate compounds on Pacific treefrog and African clawed frog embryos. Arch Environ Contam Toxicol 36:200206.

26. Nebeker AV, Schuytema GS. 2000. Effects of ammonium sulfate on growth of larval northwestern salamanders, red-legged and
Pacific treefrog tadpoles, and juvenile fathead minnows. Bull Environ Contam Toxicol 63:357-364.

27. Greulich K, Pflugmacher S. 2003. Differences in susceptibility of various life stages of amphibians to pesticide exposure. Aquat Toxicol 65:329-336.

28. Rasanen K, Laurila A, Merila J. 2002. Carry-over effects of embryonic acid conditions on development and growth of Rana temporaria tadpoles. Freshw Biol 47:19-30.

29. Gosner KL. 1960. A simplified table for staging anuran embryos and larvae with notes on identification. Herpetologica 16:183190.

30. Shi DL, Boucaut JC. 1995. The chronological development of the urodele amphibian Pleurodeles. Int J Dev Biol 39:427-441.

31. U.S. Environmental Protection Agency. 1983. Methods of chemical analysis of water and wastes. EPA-600/4-79-020. Environmental Monitoring Systems Laboratory, Cincinnati, OH.

32. Environmental Sciences Section. 1991. ESS Method 220.3: Ammonia Nitrogen and Nitrate + Nitrite Nitrogen, Automated Flow Injection Analysis Method. Wisconsin State Lab of Hygiene, Madison, WI, USA.

33. Neter J, Kutner MH, Nachtsheim CJ, Wasserman W. 1996. Applied Linear Statistical Models, 4th ed. Times Mirror Higher Education Group, Chicago, IL, USA.

34. Laposata MM, Dunson WA. 1998. Effects of boron and nitrate on hatching success of amphibian eggs. Arch Environ Contam Toxicol 35:615-619.

35. Marco A, Quilchano C, Blaustein AR. 1999. Sensitivity to nitrate and nitrite in pond-breeding amphibians from the Pacific Northwest, USA. Environ Toxicol Chem 18:2836-2839.

36. Hecnar SJ. 1995. Acute and chronic toxicity of ammonium nitrate fertilizer to amphibians from southern Ontario. Environ Toxicol Chem 14:2131-2137.

37. Watt PJ, Jarvis P. 1997. Survival analysis in palmate newts exposed to ammonium nitrate agricultural fertilizer. Ecotoxicology 6:355-362.

38. Xu Q, Oldham RS. 1997. Lethal and sublethal effects of nitrogen fertilizer ammonium nitrate on common toad (Bufo bufo) tadpoles. Arch Environ Contam Toxicol 32:298-303.

39. Foxon GEH. 1964. Blood and respiration. In Moore JA, ed, Physiology of the Amphibia. Academic, New York, NY, USA, pp 151209.

40. Jensen FB. 1995. Uptake and effects of nitrate and nitrite in animals. In Walsh PJ, Wright P, eds, Nitrogen Metabolism and Excretion. CRC, Boca Raton, FL, USA, pp 289-303. 